Patamanska, G., Mitova, I., Miteva, D., Gigova, A. (2021): Response of yield and quality of tomato grown in unheated greenhouse to irrigation and fertilization with different rates. Agriculture and Forestry, 67 (4): 43-50

DOI: 10.17707/AgricultForest.67.4.04

\begin{abstract}
Galina PATAMANSKA ${ }^{1^{*}}$, Ivanka MITOVA, Daniela MITEVA ${ }^{2}$, Antoaneta GIGOVAI ${ }^{1}$
\end{abstract}

\title{
RESPONSE OF YIELD AND QUALITY OF TOMATO GROWN IN UNHEATED GREENHOUSE TO IRRIGATION AND FERTILIZATION WITH DIFFERENT RATES
}

\begin{abstract}
SUMMARY
An experiment was conducted during 2020 on tomato variety Big Beef F1, planted in Haplic chromic luvi soil under drip irrigation with mulching and fertigation in an unheated greenhouse. The aim was to determine how the yield and quality of tomato were affected under full $\left(100 \% \mathrm{ET}_{\mathrm{c}}\right)$ and deficit irrigation $\left(60 \% \mathrm{ET}_{\mathrm{c}}\right)$ in interaction with four fertilizer rates $(120 \% \mathrm{RDF}, 100 \% \mathrm{RDF}, 80 \%$ $\mathrm{RDF}, 0 \%$ ). The total yield of tomato plants under full irrigation was $25.7 \%$ higher than the yield of the tomato plants under deficit irrigation. Full irrigation, in interaction with the fertilization rates $120 \%$ and $100 \%$ RDF of NPK, maintained $30 \%$ higher yield of tomato than the yield of plants under reduced water supply with the same fertilization rates. The following parameters: total soluble solids, $\mathrm{pH}$, reducing sugars, ascorbic acid content and titratable acidity were examined to assess the quality of tomato fruits. Except $\mathrm{pH}$, all of the quality parameters of the tomato plants, subjected to moderate stress, due to a reduction in the irrigation rate, showed higher values than those of fully irrigated plants. The $\mathrm{pH}$ trend was reversed and the parameter had higher values at full irrigation. Analysis of variance (ANOVA) was performed to analyze the effect of irrigation and fertilization with different rates. The effect of fertilization on the yield and quality of tomato was less pronounced compared to the effect of irrigation.
\end{abstract}

Keywords: Solanum lycopersicum, yield, quality, drip irrigation, greenhouse

\section{INTRODUCTION}

Modern agriculture faces the challenge, on the one hand, to maintain high yields and crop quality, while increasing water use efficiency, and on the other

\footnotetext{
${ }^{1}$ Galina Patamanska*(Corresponding author: patamanska_g@yahoo.com), Ivanka Mitova, Antoaneta Gigova, Institute of Soil Science, Agro technologies and Plant Protection "Nikola Poushkarov", Agricultural Academy, Sofia, BULGARIA

2 Daniela Miteva, Department of Food Technology, Institute of Cryobiology and Food Technology, Agricultural Academy, Sofia, BULGARIA

Paper presented at the $12^{\text {th }}$ International Scientific Agricultural Symposium "AGROSYM 2021".

Notes: The authors declare that they have no conflicts of interest. Authorship Form signed online.

Recieved:11/07/2021

Accepted:18/11/2021
} 
hand, to reduce the amount of pollutants from agricultural activities (Djurović et al., 2016; Hou M. et al., 2017; Tang et al., 2016). Inefficient irrigation and fertilization can compromise yields, degrade crop quality, and provoke the accumulation of nitrates and pesticides in soil and groundwater (Xing Ying-ying et al., 2015).

In Bulgaria tomatoes are the most common crops grown in greenhouses. Although the total greenhouse area in Bulgaria was within 916 ha in 2018, which was only $2.08 \%$ of total vegetable area, because of the high intensity of greenhouse production, the share of greenhouse tomatoes is almost $74 \%$ of those produced in the country..

Tomato has high water requirements and irrigation is needed during the cultivation. (Patane et al., 2011) In recent years, drip irrigation systems have been widely used in the greenhouses, which allow supply of the needed water for irrigation to the plants directly into the active soil layer without surface and deep water losses, with minimal losses of evaporation and filtration. Together with the drip irrigation, the mineral fertilizers are also applied to increase the yields. This process is known as fertigation. Many studies worldwide in recent years have shown that the management of water and fertilizers applied through the drip irrigation system is a prerequisite for achieving optimal yields of high quality agricultural products. Many studies have focused on the effects of drip fertigation on tomato yield and fruit quality.

The aim of this study was to determine how the yield and quality of tomato, grown in greenhouse were affected under full (100\% ETc) and deficit irrigation $(60 \% \mathrm{ETc})$ in interaction with various fertilizer rates $(120 \% \mathrm{RDF}$, $100 \%$ RDF, $80 \%$ RDF, 0\%).

\section{MATERIAL AND METHODS}

The study was conducted in the Chelopechene experimental field of the ISSAPP „Nikola Poushkarov” in town of Sofia, Bulgaria in an unheated polyethylene greenhouse with dimensions of $7.9 \times 53 \mathrm{~m}$ and a total area of 420 $\mathrm{m}^{2}$ during 2020. The experimental field with geographical coordinates: 42 ○ $44^{\prime} 22.8^{\prime \prime} \mathrm{N}, 23^{\circ} 28^{\prime} 3.7^{\prime \prime} \mathrm{E}$ is a part of the Sofia Field, located at $550 \mathrm{~m}$ above sea level. This area has continental climate characterized by cold winter. The soil is slightly humus $(2.33 \%)$ Haplic chromic luvi soil which can be defined as moderate to strong water-permeable with an average filtration capacity.

The object of the study are tomato variety "Big Beef" F1. A two-factor experiment was performed with experimental factors - irrigation (V) and fertilization (T). The factor irrigation was applied in two levels: V1 - full irrigation at irrigation rate estimated by evapotranspiration (100\% ETc) and V2 deficit irrigation $(60 \% \mathrm{ETc})$. The factor fertilization was applied at four levels: T0 - without fertilizer, $\mathrm{T} 1$ - suboptimal fertilization $\mathrm{N}_{8.95} \mathrm{P}_{11.82} \mathrm{~K}_{3.87}, \mathrm{~T} 2$ - optimal fertilization $\mathrm{N}_{11.59} \mathrm{P}_{15.84} \mathrm{~K}_{17.74}, \mathrm{~T} 3$ - luxury fertilization $\mathrm{N}_{14.50} \mathrm{P}_{20.13} \mathrm{~K}_{21.88}$. The experimental treatments V1T0, V1T1, V1T2, V1T3, V2T0, V2T1, V2T2, V2T3 were arranged according to the method with long plots. Each plot has a surface of 
$24 \mathrm{~m}^{2}$ and consisted of twin rows of tomato with a total of 81 plants. They are planted „checkerboard“ at a spacing of $0.6 \mathrm{~m}$ and at a distance between rows of $0.5 \mathrm{~m}$.

Irrigation was performed with a drip irrigation system, comprising a command unit and two batteries consisting eight laterals situated next to the each row of tomato. Mulching was applied to further reducing the evaporation. Black polyethylene mulch (UV $15 \mathrm{mic} / 1.20 \mathrm{~m}$ ) was used. Immediately after planting the tomatoes in a permanent place, a watering of 1-2 1 per plant was carried out to intercept seedlings and next watering 7 days later. Depending on the growth stage of tomatoes, watering was carried out with a frequency of 3-7 days. Deficit irrigation began to apply from the beginning of fruit setting.

The irrigation rate for the fully irrigated treatments was determined by the sum of daily evapotranspiration for the irrigation interval. The microclimate parameters temperature, relative humidity of the air and the solar radiation in the greenhouse required for the calculations of the evapotranspiration using the Penman-Monteith method (Allen et al., 1998) were measured with an automatic weather micro station located in the centre of the greenhouse. The average monthly data of the parameters during the entire growing season from May to September are shown in Table 1 . The conditions were favorable for medium early cultivation of tomato.

Table 1. Average microclimatic conditions in greenhouse

\begin{tabular}{|l|c|c|c|c|}
\hline \multirow{2}{*}{ Month } & \multirow{2}{*}{$\begin{array}{c}\text { Solar Radiation } \\
\mathrm{W} / \mathrm{m}^{2}\end{array}$} & \multicolumn{2}{|c|}{ Temperature } & \multirow{2}{*}{$\begin{array}{c}\mathrm{RH}_{\text {mean }} \\
\%\end{array}$} \\
\cline { 3 - 4 } & 132.98 & 2.64 & 51.14 & 57.77 \\
\hline May & 169.01 & 5.26 & 43.95 & 66.25 \\
\hline June & 190.08 & 9.34 & 44.91 & 60.75 \\
\hline July & 168.85 & 10.47 & 45.53 & 63.79 \\
\hline August & 144.92 & 3.99 & 42.98 & 55.01 \\
\hline September & & & & \\
\hline
\end{tabular}

In the autumn 2019, the main plot was fertilized with combined fertilizer $\mathrm{N}_{15} \mathrm{P}_{15} \mathrm{~K}_{15}$ at a rate of $450 \mathrm{~kg}$ per ha. During the growing season of tomato simultaneously with irrigation, 100\% water-soluble fertilizer with 120:100:80:0 fertilizer dose was given in the treatments 9 times at 7 days interval beginning 10 days after transplanting.

Harvesting of tomato fruits begins on the 80th day and continued until the 140th day after transplanting. Average samples of tomato fruits were taken of each treatment in four representative harvests and the physico-chemical analyzes were performed for determination of the following quality paramaters: Total Soluble Solids (TSS) - with moisture analyser Kern; Active Acidity $(\mathrm{pH})$ - with Hanna pH meter; Titratable Acidity (TA) - by titrimetric method with 
$0,1 \mathrm{nNaOH}$; ascorbic acid (Vitamin C) content - by the Moore method - titration with 2,6-dichlorophenol-indophenol; Reducing Sugars (RS) - by the Shoorl method.

Experimental results were expressed as mean. Data were analyzed by and two-way ANOVA performed for significance level $\mathrm{p} \leq 0.05$ using SPSS software, version 19 (IBM Microsoft, New York, USA).

\section{RESULTS AND DISCUSSION}

The results of the analysis of the quality of tomato fruits are shown in Table 2. As shown the studied quality parameters of tomato fruits differed significantly in the two irrigation regimes. They were also affected by the fertigation levels. The highest values of the parameters: TSS $(9.35 \%)$, reduced sugars $(4.73 \%)$ and titratable acidity $(0.44 \%)$ were obtained under deficit irrigation and fertigation with $100 \% \mathrm{RDF}$ and for the parameter ascorbic acid content $(41.67 \mathrm{mg} \%)$ in fertigation with $120 \%$ RDF. Only the maximum value for the $\mathrm{pH}$ parameter was at full irrigation without fertigation $(4.33 \%)$. Minimum values of the parameters reduced sugars (3.71\%) and ascorbic acid content $(27.87$ $\mathrm{mg} \%$ ) were obtained under full irrigation and fertigation with $120 \%$ RDF, also for titratable acidity $(0.23 \%)$ under full irrigation and fertigation with $100 \%$ RDF. The values of TSS parameter(6.68\%) under full irrigation and the $\mathrm{pH}$ parameter (4.09) under deficit irrigation without fertigation were the lowest.

Table 2. Average data of quality parameters of tomato and yield by treatments

\begin{tabular}{|c|c|c|c|c|c|c|c|}
\hline $\begin{array}{c}\text { Parameter } \\
\text { Treatments }\end{array}$ & $\begin{array}{c}\text { Total } \\
\text { soluble } \\
\text { solids, } \\
\%\end{array}$ & $\begin{array}{c}\mathrm{pH} \\
\%\end{array}$ & $\begin{array}{c}\text { Reducing } \\
\text { sugars, } \\
\%\end{array}$ & $\begin{array}{c}\text { Vitamin } \\
\mathrm{C}, \\
\mathrm{mg} \%\end{array}$ & $\begin{array}{c}\text { Titratable } \\
\text { acidity, } \\
\%\end{array}$ & $\begin{array}{c}\text { Total } \\
\text { Yield, } \\
\mathrm{t} \mathrm{ha}^{-1}\end{array}$ & $\begin{array}{c}\text { Yield } \\
\text { per } \\
\text { plant, } \\
\mathrm{kg}\end{array}$ \\
\hline V1T0 & 6.68 & 4.33 & 3.80 & 30.14 & 0.28 & 89.21 & 2.64 \\
\hline V1T1 & 7.49 & 4.24 & 4.05 & 28.03 & 0.30 & 89.88 & 2.66 \\
\hline V1T2 & 6.72 & 4.27 & 3.93 & 29.28 & 0.23 & 106.10 & 3.14 \\
\hline V1T3 & 6.87 & 4.27 & 3.71 & 27.87 & 0.24 & 128.33 & 3.80 \\
\hline V2T0 & 7.08 & 4.09 & 3.96 & 34.01 & 0.31 & 69.66 & 2.06 \\
\hline V2T1 & 8.61 & 4.19 & 4.33 & 34.56 & 0.35 & 70.15 & 2.08 \\
\hline V2T2 & 9.35 & 4.19 & 4.73 & 37.00 & 0.44 & 77.37 & 2.29 \\
\hline V2T3 & 8.69 & 4.22 & 4.44 & 41.67 & 0.38 & 90.07 & 2.67 \\
\hline
\end{tabular}

The results of the analysis of variance to establish the statistical differences between the treatments of the experiment in the studied parameters of tomatoes are shown in Table 3. Statistically significant differences of the treatments with different levels of irrigation in terms of TSS parameter, ascorbic acid content, titratable acidity in tomato fruits have been proven. Regarding the ascorbic acid content parameter, they have the lowest level of statistical significance $p<0.05$, 
for the TSS parameter, they have the higher level $\mathrm{p}<0.01$ and for the titratable acidity parameter, they have the highest level $\mathrm{p}<0.001$. The results of the interaction between irrigation regimes and fertigation with different levels for all studied quality parameters are also shown in Table 3. No significant interactions between the applied experimental factors for the quality parameters of tomato fruits have been proven.

Table 3. Quality parameters of tomato and yield as affected by irrigation and fertilization

\begin{tabular}{|l|c|c|c|c|c|c|c|}
\hline $\begin{array}{l}\text { Parameter } \\
\text { Irrigation } \\
\text { Regimes }\end{array}$ & $\begin{array}{c}\text { Total } \\
\text { soluble } \\
\text { solids, } \\
\%\end{array}$ & $\begin{array}{c}\mathrm{pH} \\
\%\end{array}$ & $\begin{array}{c}\text { Reducing } \\
\text { sugars, } \\
\%\end{array}$ & $\begin{array}{c}\text { Vitamin } \\
\mathrm{C}, \\
\mathrm{mg} \%\end{array}$ & $\begin{array}{c}\text { Titratable } \\
\text { acidity, } \\
\%\end{array}$ & $\begin{array}{c}\text { Total } \\
\text { Yield } \\
\mathrm{t} \mathrm{ha}^{-1}\end{array}$ & $\begin{array}{c}\text { Yield } \\
\text { per } \\
\text { Plant } \\
\mathrm{kg}\end{array}$ \\
\hline V1 & 6.939 & 4.276 & 3.874 & 28.831 & 0.261 & 76.813 & 2.275 \\
\hline V2 & 8.433 & 4.171 & 4.367 & 36.812 & 0.370 & 103.380 & 3.060 \\
\hline F-Ratio & 9.436 & 3.508 & 3.961 & 6.150 & 21.289 & 6.594 & 6.539 \\
\hline P-Value & 0.004 & $\mathrm{~ns}$ & $\mathrm{~ns}$ & 0.019 & 0.000 & 0.042 & 0.043 \\
\hline
\end{tabular}

\section{Fertigation Levels}

\begin{tabular}{|l|c|c|c|c|c|c|c|}
\hline T0 & 6.883 & 4.211 & 3.880 & 32.076 & 0.294 & 79.435 & 2.350 \\
\hline T1 & 8.048 & 4.212 & 4.193 & 31.295 & 0.326 & 80.015 & 2.370 \\
\hline T2 & 8.034 & 4.229 & 4.333 & 33.143 & 0.333 & 91.735 & 2.715 \\
\hline T3 & 7.780 & 4.242 & 4.076 & 34.771 & 0.310 & 109.200 & 3.235 \\
\hline F-Ratio & 1.003 & 0.059 & 0.520 & 0.172 & 0.304 & 1.016 & 1.025 \\
\hline p-Value & $\mathrm{ns}$ & $\mathrm{ns}$ & $\mathrm{ns}$ & $\mathrm{ns}$ & $\mathrm{ns}$ & $\mathrm{ns}$ & $\mathrm{ns}$ \\
\hline Interaction VxT & & & & & & & \\
\hline F-Ratio & 2.057 & 0.226 & 0.066 & 0.603 & 0.826 & 4.048 & 4.018 \\
\hline p-Value & $\mathrm{ns}$ & $\mathrm{ns}$ & $\mathrm{ns}$ & $\mathrm{ns}$ & $\mathrm{ns}$ & 0.025 & 0.026 \\
\hline
\end{tabular}

ns - not significant

The results obtained in the study show that the quality parameters: ascorbic acid content, titratable acidity and reduced sugars at both levels of irrigation for tomato plants with fertigation are higher than the those obtained by Milenkovic et al., 2018 in experiment with the same tomato variety under conventional application of fertilizers to the soil and shading coatings.

Correlation analysis was performed to establish a relationship between the various quality parameters of tomato. The results showed significant correlations between the studied quality parameters (Table 4). 
Table 4: Correlation between tomato quality parameters

\begin{tabular}{|c|c|c|c|c|c|}
\hline Parameter & Vit.C & TSS & $\mathrm{pH}$ & TA & RS \\
\hline Vit.C & 1 & $.778^{*}$ & -0.48 & $.821^{*}$ & $.790^{*}$ \\
\hline TSS & $.778^{*}$ & 1 & -0.405 & $.942^{* *}$ & $.970^{* *}$ \\
\hline $\mathrm{pH}$ & -0.48 & -0.405 & 1 & -0.489 & -0.414 \\
\hline TA & $.821^{*}$ & $.942^{* *}$ & -0.489 & 1 & $.944^{* *}$ \\
\hline RS & $.790^{*}$ & $.970^{* *}$ & -0.414 & $.944^{* *}$ & 1 \\
\hline
\end{tabular}

* Correlation is significant at the 0.05 level (2-tailed).

**.Correlation is significant at the 0.01 level (2-tailed).

Ascorbic acid content has a significant positive correlation with TSS, TA and RS ( $\mathrm{p}<0.05)$. On the other hand, Vitamin $\mathrm{C}$ parameter, as well as the other quality parameters TSS, TA and RS are negatively correlated with $\mathrm{pH}$. For all parameters the correlation with $\mathrm{pH}$ is not significant. There is also a significant positive relationship between TA on the one hand and TSS and RS on the other (p $<0.01)$.

Table 5. Regression equations for the quality parameters

\begin{tabular}{|c|c|}
\hline Relationship & $\mathbf{R}^{2}$ \\
\hline Vit. $C=56.364 \mathrm{TA}+15.021$ & 0.674 \\
\hline Vit. $C=0.056 R S+2.265$ & 0.624 \\
\hline $\mathrm{TSS}=0.0642 \mathrm{TA}-0.177$ & 0.887 \\
\hline$=2.899 \mathrm{RS}-4.255$ & 0.94 \\
\hline$=13.818 \mathrm{TSS}+3.322$ & 0.887 \\
\hline$=0.192 \mathrm{RS}-0.476$ & 0.891 \\
\hline$=4.633 \mathrm{TA}+2.656$ & 0.891 \\
\hline$=0.324 \mathrm{TSS}+1.626$ & 0.94 \\
\hline
\end{tabular}

Using linear regression analysis empirical dependences have been derived between the quality parameters of tomato fruits for which a significant correlation has been established. Table 5 shows the obtained linear regression models as well as the coefficient of determination. The equations are statistically significant at the $p=0.05$ level. The coefficients in front of the independent variable as well as the free term of the linear regression models are statistically significant at the same level of significance $(\mathrm{p}<0.05)$ and higher $(\mathrm{p}<0.01)$. The level of significance of the models and their coefficients shows that the obtained regression models correspond well to the experimental data. 
Table 5 shows that the relationship between the TSS and reducing sugars in tomato fruits has a high coefficient of determination $\mathrm{R}^{2}=0.94$. Literature data are available for the correlation between TSS and reducing sugars, which is due to of reduced water content in tomato (Anthon et al., 2011; Mitova and Dinev, 2011). A high coefficient of determination $\mathrm{R}$ was also obtained for the linear equations describing the dependences: titratable acidity from the TSS $\left(\mathrm{R}^{2}=0.887\right)$ and titratable acidity from the reducing sugars $\left(\mathrm{R}^{2}=0.891\right)$.

Experimental results for the tomato yield by treatments are given in Table 2. The results of the statistical analysis, showing the influence of irrigation and fertilization with different irrigation and fertilizer rates, are given in Table 3. Significantly higher yields were obtained in the fully irrigated treatments, as the highest yield per plant $\left(3.8 \mathrm{~kg}\right.$ per plant) and total yield $\left(128.33 \mathrm{t} \mathrm{ha}^{-1}\right)$ was obtained from tomato plants receiving $100 \%$ irrigation rate and fertigation with $120 \%$ RDF.

The yield of tomatoes plants under deficit irrigation was lower than those of fully irrigated plants, as the highest yield $\left(90.7 \mathrm{t} \mathrm{ha}^{-1}\right)$ and yield per plant (2.67 $\mathrm{kg}$ per plant) was obtained at the application of the maximum fertilizer rate (120\% RDF). Therefore, the yield of tomatoes differed significantly depending on the levels of fertigation. The application of fertigation with $120 \%$ RDF achieved the highest yield, while applying fertigation with $80 \%$ RDF registered a significantly of $10 \%$ to $30 \%$ lower yield compared to those in higher levels of fertigation.The total yield of tomato plants under full irrigation was higher by $25.7 \%$ than the yield of plants under deficit irrigation. Full irrigation, applied with luxury and optimal fertilization, maintained $30 \%$ higher yield than the yield of tomato plants subjected to moderate stress due to reduced irrigation rate under same fertilization.

The yield of tomatoes obtained in this study is comparable in size with that obtained by Milenković et al., 2018. In the present study, the yield per plant was lower $-2.28 \mathrm{~kg}$ per plant under deficit irrigation and $3.06 \mathrm{~kg}$ per plant under full irrigation, while in the experiment of Milenković et al., 2018, the yields of the hybrid Big Beef F1 range between 3.2 and $5.1 \mathrm{~kg}$ per plant. The larger number of plants per unit area in the experiment conducted in Bulgaria was the reason for the reducing food area and for more unfavorable light conditions, which have been affected the fruiting of the plants.

\section{CONCLUSIONS}

The results obtained from the quality analysis determine the production of tomatoes as such with high quality parameters: TSS between 6.72 and $9.35 \% ; \mathrm{pH}$, which varies in a small range of 4.09 to $4.33 \%$, titratable acidity with relatively low content $-0.23-0.44 \%$; reducing sugars $-3.71-4.73 \%$ and ascorbic acid between 27.87 and $41.67 \mathrm{mg} \%$. With the exception of $\mathrm{pH}$, all others quality parameters of tomato plants subjected to moderate stress due to a reduction in irrigation rate show higher values than those of fully irrigated plants. It can be concluded that deficit irrigation improves the quality of tomato fruits in terms of 
TSS, ascorbic acid, reduced sugars and titratable acidity. A significant correlation was found between the studied quality parameters and linear regression equations with high value of the coefficient of determination $\mathrm{R}^{2}$ were obtained.

The total yield of tomato plants subjected to full irrigation was higher by $25.7 \%$ than the yield of plants subjected to deficit irrigation. It has been found that combining irrigation levels with different levels of fertigation affects tomato yield. The results show that the yield in the treatments with the application of the highest fertilizer rate is the highest for both full and deficit irrigation (128.33 and $90.07 \mathrm{t} / \mathrm{ha})$.

Statistical analysis of the experimental data showed that the effect of fertilization on the yield and quality of tomatoes was less pronounced compared to the effect of irrigation.

\section{ACKNOWLEDGEMENT}

The present work is based on researches that are funded from the Bulgarian National Science Fund of the Ministry of Education and Science under a bilateral cooperation project between Bulgaria and China, contract number КП-06Китай/1.

\section{REFERENCES}

Allen, R.G., L.S. Pereira, D. Raes and M. Smith. 1998. Crop evapotranspiration: guidelines for computing crop water requirements. Irrigation and Drainage Paper 56, FAO, Rome.

Anthon,G., Strange,M. and D.Barrett, (2011). Changes in pH, acids, sugars and other quality parameters during extended vine holding of ripe processing tomatoes. Journal of the Science of Food and Agriculture. Vol.91, 7: 1175-1181

Djurović, N., Ćosić, M., Stričević, R., Savić, S., and Domazet, M. 2016. Effect of irrigation regime and application of kaolin on yield, quality and water use efficiency of tomato. Sci. Hortic. 201, 271-278. doi: 10.1016/j.scienta.2016.02.017

Patane, C., S. Tringali, and O. Sortino, 2011. Effects of deficit irrigation on biomass, yield, water productivity and fruit quality of processing tomato under semi-arid Mediterranean climate conditions. Sci. Hortic 129, 590-596 .

Hou M, Jin Q, Lu X, Li J, Zhong H and Gao Y., (2017). Growth, Water Use, and Nitrate$15 \mathrm{~N}$ Uptake of Greenhouse Tomato as Influenced by Different Irrigation Patterns, 15N Labeled Depths, and Transplant Times. Front. Plant Sci. 8:666. doi: 10.3389/fpls.2017.00666

Tang, K., Gong, C., and Wang, D. (2016). Reduction potential, shadow prices, and pollution costs of agricultural pollutants in China. Sci. Total Environ. 541, 42-50.

Xing Ying-ying, ZHANG Fu-cang, ZHANG Yan, LI Jing, QIANG Sheng-cai, WU Lifeng. (2015). Effect of Irrigation and Fertilizer Coupling on Greenhouse Tomato Yield, Quality, Water and Nitrogen Utilization Under Fertigation [J].Scientia Agricultura Sinica, 2015, 48(4): 713-726

Milenković L, Mastilović J, Kevrešan Z, Jakšić A, Gledić A, et al., (2018). Tomato Fruit Yield and Quality as Affected by Grafting and Shading. HSOA Journal of Food Science and Nutrition . Volume 4, Issue 3, pp. 2- 9: 100042.

Mitova Iv., N. Dinev, (2011). Comparative study of organic and mineral fertilization on nutrient absorption and quality of tomato fruit. Soil Science, Agrochemistry and Ecology, Year XLV, Appendix 1-4, 164-169.(Bg) 